\title{
CHANGES IN MORPHOLOGICAL AND CYTOLOGICAL PROPERTIES OF BLOOD DURING PHYSICAL EXERCISE IN WATER AT $4^{\circ} \mathrm{C}$ AND $25^{\circ} \mathrm{C}$
}

\author{
Aneta Teległów ${ }^{1(\mathrm{~A}-\mathrm{F})}, J^{\prime}$ Jilski $^{2(\mathrm{D}, \mathrm{E}, \mathrm{F})}$, Zbigniew Dąbrowski $^{1(\mathrm{~A}, \mathrm{D}, \mathrm{E}, \mathrm{F})}$, Anna Marchewka ${ }^{1(\mathrm{D}, \mathrm{E}, \mathrm{F})}$, \\ Jerzy Jaśkiewicz ${ }^{3(\mathrm{D}, \mathrm{E}, \mathrm{F})}$, Jacek Głodzik ${ }^{4(\mathrm{D}, \mathrm{F})}$, Magdalena Kępińska ${ }^{5(\mathrm{~F})}$, Dorota Lizak $^{3(\mathrm{~F})}$
}

${ }^{1}$ Department of Clinical Rehabilitation, University School of Physical Education in Cracow, Poland ${ }^{2}$ Department of Ergonomics and Exercise Physiology, Collegium Medicum, Jagiellonian University in Cracow, Poland

${ }^{3}$ Department of Health and Medical Sciences, Andrzej Frycz Modrzewski Cracow University, Poland ${ }^{4}$ Department of Physiotherapy, University School of Physical Education in Cracow, Poland

${ }^{5}$ Doctoral student, University School of Physical Education in Cracow, Poland

\begin{abstract}
Objective: The aim of this study was to determine the effect of a single swimming exercise till exhaustion, in water on the morphological and cytological blood parameters in laboratory rats.

Methods: The experiment involved 60 male rats from the Wistar strain, aged 8 weeks and 36 weeks. The animals were separated into 6 groups: 3 groups (I, II, III) of 8-week old animals, and 3 groups (IV, V, VI) of 36 -week old animals. The rats in the study groups i.e. II, III, V, and VI were made to swim till exhaustion in water at $4^{\circ} \mathrm{C}$ and at $25^{\circ} \mathrm{C}$. After the experiment blood samples were collected from each rat and hematological and cytological determinations were completed for each sample.

Results: Compared with the control group, in the rats from group II (8-week old, swimming in water at $4^{\circ} \mathrm{C}$ ) a significant increase was noted in the $\mathrm{RBC}$ count, $\mathrm{Hb}, \mathrm{Ht}$, and $\mathrm{MCHC}$, and $\mathrm{MCH}$ indices, whereas in the rats from group $\mathrm{V}$ (36-week old, swimming in water at $4^{\circ} \mathrm{C}$ ) increases were noted in the $\mathrm{MCHC}$ and $\mathrm{MCH}$ indices (again when compared with the control group). In the rats from group III (8-week old, swimming in water at $25^{\circ} \mathrm{C}$ ), compared with the control group, significant increases were noted in the $\mathrm{Hb}$ and $\mathrm{Ht}$ parameters, as well as in the $\mathrm{MCHC}$, and $\mathrm{MCH}$ indices, whereas in the group $\mathrm{VI}$ rats (36-week old swimming at $25^{\circ} \mathrm{C}$ ) - the increase was noted in the $\mathrm{MCHC}$ index. No alterations were found in the reticulocyte count, and in poikilocytes during exercise in water at low temperatures in either the 8-week or 36-week old rats.

Conclusions: The increases in the majority of blood parameters, testifies to the dehydration of the body during physical exercise which in turn affects the microcirculation function. The lack of alterations in the reticulocyte count in the peripheral blood may, in turn, testify to the ineffectiveness of low temperature during exercise upon the function of the bone marrow.
\end{abstract}

Key words: swimming, hematology, body temperature, temperature of blood, femoral vein and artery

\section{Introduction}

Blood is a liquid connective tissue, circulating in blood vessels. Owing to its movements it ensures close contact between various parts and cells of the organism. Under the impact of a single physical exercise, the increases in hemoglobin $(\mathrm{Hb})$ concentration, hematocrit (Ht), and the erythrocyte count (RBC) are observed in the red blood cells system. The underlying reason for these changes is dehydration of the organism which entails a decrease in the volume of plasma and increased density of the blood. The decrease in the volume of plasma is affected by the loss of water through the respiratory system and skin, as well as the shift of water from the vessels into extravascular space. The decrease in the volume of plasma was also observed in humans staying in water at low temperatures. This process is associated with a slower release of the antidiuretic hormone which leads to increased diuresis, which is explained by the authors as plasma water permeating through to the intercellular space and hemoconcentration of the plasma [1]. Because of the difficulties in studying the effect of low temperatures upon humans, such experiments are often carried out on animals. The differences in the effect of acclimation, to temperatures dropping from $20^{\circ} \mathrm{C}$ to $4^{\circ} \mathrm{C}$ on the hematological indices, were studied by Deveci et al. [2]. In experimental animals, these authors demonstrated that such a decrease in temperatures caused a significant increase in the oxygen carrying capacity of blood as well as the metabolic rate, which was further supported by the increased red blood cell count, hematocrit and hemoglobin. The higher values for RBC, HB, HT, in this study are consistent with an increased metabolic rate in rats.

The above findings concur with the results of earlier studies by the same authors, who showed that the carrying capacity for oxygen carried by blood increased as a result of elevated metabolic activity prompted by a lower temperature. Ruckman et al. [3] demonstrated the significant increases in the level of hemoglobin and 
hematocrit in rats during swimming at $32-35^{\circ} \mathrm{C}$. The rapid release from blood 'reservoirs' (such as the liver and spleen), are considered to be the cause of the increased numbers of erythrocytes in the peripheral blood stream. A significant role in this process is attributed to the spleen. Under the impact of catecholamines released in higher quantities during the stress of exercise, the spleen undergoes shrinkage and ejects red blood cells previously stored into the blood circulatory.

At the same time, with the beginning of the physical exercise there is a transient shift of water from the plasma to the cytosol of the erythrocytes, resulting in their increased volumes. In another study, increased $\mathrm{Hb}$ levels were noted in 4-month old rats trained to swim, after a period spent at an elevation of $5700 \mathrm{~m}$ a.s.l. [4]. The authors of the study explain this by surmising that the increase in the former group may be due to the fact that training can induce a shorter life span for erythrocytes, leading to younger cells that emerge with a better antioxidant defense.

A similar phenomenon was observed by Holmer [5] who studied men who after 2-3 weeks of acclimation in cold water, had increased RBC counts and $\mathrm{Hb}$ concentrations. Also of consideration is the fact that in $10 \%$ of such swimmers, low Hb levels and accompanying intravascular hemolysis occurred, which caused anemia [6].

Swimming in water at $4^{\circ} \mathrm{C}$ leads to marked hypothermia while no significant changes were observed as a result of swimming at $25^{\circ} \mathrm{C}$. However, besides acute one, also moderate hypothermia can be reflected by hemorheological changes. Our previous studies revealed that 8 -week-old rat are characterized by more pronounced changes in hemoconcentration resulting from worse adaptive abilities.

The objective of our study was to subject 8 and 36week old rats to a single exercise at low temperature (in water at $4^{\circ} \mathrm{C}$ and $25^{\circ} \mathrm{C}$ ) and to study its impact on the morphological and cytological parameters of blood.

\section{Methods}

\section{Animals}

In the experiments, 30 male 8-week-old Wistar rats, and 30 male 36-week-old Wistar rats were used.
Eight weeks of age correspond to minimal age of sexual maturity in rats [7] while 36 weeks of age correspond to time when initial signs of aging manifest in adult rats. The rats were divided into 6 research groups: control, swimming in water at $4^{\circ} \mathrm{C}$ and swimming in water at $25^{\circ} \mathrm{C}$. These temperatures of water were selected based on literature data [8]. Temperature of $4^{\circ} \mathrm{C}$ is life threatening temperature. Temperature of $25^{\circ} \mathrm{C}$, in turn, was considered reference temperature since it is typical for most swimming pools, and can cause moderate hypothermia in rats. Prior to the commencement of the experiment, a number of preliminary trials were carried out in order to determine the right duration time for swimming in water at $4^{\circ} \mathrm{C}$ and $25^{\circ} \mathrm{C}$, and to observe at what point the animals gave up swimming. The animals were taken from the breeding centre of the Department of Animal Physiology, Institute of Zoology, Jagiellonian University in Cracow. The rats were kept in an animal room, in separate cages, with food and water available, under a 12/12-hour day/night cycle (light-darkness). They were fed a standard mix for rodents produced by Labofeed $\mathrm{H}$.

The experiments for which the consent of the Local Bioethics Committee of the Jagiellonian University was obtained, was carried out in the Department of Animal Physiology, Institute of Zoology, Jagiellonian University. Experiments were conducted between 9 am and 12 noon. The animals swam in a glass tank $120 \mathrm{~cm}$ wide, $40-\mathrm{cm}$ wide, and 50-cm deep. The temperature of the water in the tank was checked using a laboratory thermometer (PT-217, Elmetron). After the experiment the rectal temperature was measured in each rat. After completion of the experiment the animals were killed by spinal dislocation, after which the femoral artery and vein were cut open and $2 \mathrm{ml}$ of blood extracted from them and placed in Vacuette-type test tubes with potassium EDTA. At the same time, the temperatures of blood flowing from the femoral vein and artery were measured with a clinical thermometer.

\section{Measuring the basic hematological parameters}

The blood collected in $10 \mu \mathrm{l}$ samples was used to determine the basic hematological measurements, using a veterinary analyzer for animal blood $A B X-A B C$ Vet,

Table 1. Description of experimental animals and conditions

\begin{tabular}{|c|c|c|c|c|c|c|}
\hline Group & Age (weeks) & $\begin{array}{c}\text { Not swimming } \\
\text { (control) }\end{array}$ & $\begin{array}{l}\text { Swimming at } 4^{\circ} \mathrm{C} \\
(\min , \text { mean } \pm \mathrm{SD})\end{array}$ & $\begin{array}{l}\text { Swimming at } \\
25^{\circ} \mathrm{C} \text { (min) }\end{array}$ & $\begin{array}{l}\text { Weight } \\
\text { (g) }\end{array}$ & $n$ \\
\hline I & 8 & yes & - & - & $373.6 \pm 15.47$ & 10 \\
\hline II & 8 & - & $4.42 \pm 0.73$ & - & $322.3 \pm 15.12$ & 10 \\
\hline III & 8 & - & - & 60 & $311.0 \pm 14.59$ & 10 \\
\hline IV & 36 & yes & - & - & $529.0 \pm 10.7$ & 10 \\
\hline V & 36 & - & $4.92 \pm 0.45$ & - & $527.8 \pm 19.98$ & 10 \\
\hline VI & 36 & - & - & 60 & $530.8 \pm 13.68$ & 10 \\
\hline
\end{tabular}


manufactured by $A B X$ Diagnostics (France) according to the methodology described by Pińkowski [9]. The following parameters were determined: red blood cell count: RBC $\left(10^{6} / \mathrm{mm}^{3}\right)$, hematocrit: Ht (\%), hemoglobin: $\mathrm{Hb}$ (g/dl), mean corpuscular hemoglobin: $\mathrm{MCH}$ (pg), mean corpuscular volume: $\mathrm{MCV}\left(\mu \mathrm{m}^{3}\right)$, mean cell hemoglobin concentration: $\mathrm{MCHC}(\mathrm{g} / \mathrm{dl})$, white blood cell count: WBC $\left(10^{3} / \mathrm{mm}^{3}\right)$, platelet number: $\operatorname{PLT}\left(10^{3} / \mathrm{mm}^{3}\right)$.

\section{Cytological determinations}

\section{Reticulocyte determination}

Intra-vital staining according to Heath and Daland [10] was used. The reticulocytes were counted in each 1000 of erythrocytes encountered. The results are given as $\%$. The reticulocytes were classified acc. to Heilmeyer and Trachtenberg [11], who divided them into groups 0 , I, II, III, and IV, reflecting the stages of reticulocyte development.

\section{Determinations of poikilocytes}

The shape assessments of the poikilocytes (erythrocytes deviating from normal shape) was undertaken according to the methods proposed by Chirico et al. [12] and Holowińska [13]. In smears stained using the Wright-Giemsa method, the percentage composition of poikilocytes was estimated by counting the poikilocytes in every 1000 of encountered erythrocytes. The results were given in percentages.

\section{Statistical analysis}

Continues variables were presented as arithmetic means along with their standard deviations, ranges, medians, and lower and upper quartiles. The normality of distribution was tested using the Shapiro-Wilk test. Arithmetic means between groups of rats subjected to exercise at $4^{\circ} \mathrm{C}$ or $25^{\circ} \mathrm{C}$ and the controls were compared with one-way ANOVA and Tukey post-hoc test or with Kruskal-Wallis ANOVA. Calculations were performed using Statistica 7 (StatSoft', Poland) software, and statistical significance was defined as $P \leq 0.05$.

\section{Results}

Body temperature and temperature of blood flowing from the femoral vein and artery

When considering the values of post-exercise temperature of blood flowing from the femoral vein and artery in three groups of 8 -week old rats (I, II, III), it was shown that there were statistically significant differences between these groups. After the analysis of bilateral comparisons (value of median), it turned out that the mean value of body temperature and post-exercise temperature of blood flowing from the femoral vein and artery, were significantly lower in rats swimming in water at $4^{\circ} \mathrm{C}$ compared with the control group of rats and compared with rats swimming in water at $25^{\circ} \mathrm{C}$ (Table 2 ).

The values of post-exercise body (rectal) temperature decreased in group II (8-week old rats swimming in water at $4^{\circ} \mathrm{C}$ ) in comparison with control group I by $17.2^{\circ} \mathrm{C}$ and in comparison with group III (of rats swimming in water at $25^{\circ} \mathrm{C}$ ), by $5.8^{\circ} \mathrm{C}$ (Table 2 ).

The values of post-exercise temperature of blood flowing from the femoral vein and artery decreased in group II (8-week old rats swimming in water at $4^{\circ} \mathrm{C}$ ), in comparison with control group I by $10.5^{\circ} \mathrm{C}$ and in comparison with group III (of rats swimming in water at $25^{\circ} \mathrm{C}$ ) by $11.91^{\circ} \mathrm{C}$ (Table 2 ) .

When considering the values of post-exercise temperature of blood flowing from the femoral vein and artery in three groups of 36-week old rats (IV, V, VI), it was shown that there were statistically significant differences between these groups. In post-hoc tests (see Table 3), it turned out that the mean value of post-exercise temperature of blood flowing from the femoral vein and artery was significantly lower in rats swimming in water at $4^{\circ} \mathrm{C}$ compared with the control group of rats, between the control group and the group of rats swimming in water at $25^{\circ} \mathrm{C}$ (Table 3 ).

The values of post-exercise body (rectal) temperature decreased in group $\mathrm{V}$ (in 36-week old rats swimming in water at $4^{\circ} \mathrm{C}$ ) compared with the control group IV, by $12.84^{\circ} \mathrm{C}$ and in group VI (36-week old

Table 2. Median values (interquartile ranges) of body temperature and temperature of blood flowing from the femoral vein and artery in 8-week old rats swimming in water at $4^{\circ} \mathrm{C}$ or $25^{\circ} \mathrm{C}$ and in controls

\begin{tabular}{cccc}
\hline & $\begin{array}{c}\text { Group I } \\
\text { Control }\end{array}$ & $\begin{array}{c}\text { Group II } \\
\text { Swimming at } 4{ }^{\circ} \mathrm{C}\end{array}$ & $\begin{array}{c}\text { Group III } \\
\text { Swimming at } 25^{\circ} \mathrm{C}\end{array}$ \\
\hline $\begin{array}{c}\text { Body temperature } \\
{\left[{ }^{\circ} \mathrm{C}\right]}\end{array}$ & $\begin{array}{c}36.6^{\circ} \mathrm{C} \\
(36.0-36.9)\end{array}$ & $\begin{array}{c}19.4^{\circ} \mathrm{C} \\
(19.0-20.0)^{*},{ }^{* *}\end{array}$ & $\left(25.2^{\circ} \mathrm{C}\right.$ \\
$\begin{array}{c}\text { Post-exercise temperature } \\
\text { of blood flowing from the } \\
\text { femoral vein and artery }\end{array}$ & $33.3 \mathrm{C}$ & $22.8 \mathrm{C}$ \\
{$\left[{ }^{\circ} \mathrm{C}\right]$} & $(32.3-34.0)$ & $(22.3-23.6)^{*},{ }^{* *}$ & $25.0 \mathrm{C}$ \\
\end{tabular}

${ }^{*}$ significantly different compared to controls $(P<0.05)$

${ }^{*}$ significantly different between groups II and III $(P<0.05)$ 
Table 3. Mean values $( \pm S D)$ of body temperature and temperature of blood flowing from the femoral vein and artery in $36-$ week old rats swimming in water at $4^{\circ} \mathrm{C}$ or $25^{\circ} \mathrm{C}$ and in controls

\begin{tabular}{|c|c|c|c|}
\hline & $\begin{array}{c}\text { Group IV } \\
\text { Control }\end{array}$ & $\begin{array}{c}\text { Group V } \\
\text { Swimming at } 4^{\circ} \mathrm{C}\end{array}$ & $\begin{array}{c}\text { Group VI } \\
\text { Swimming at } 25^{\circ} \mathrm{C}\end{array}$ \\
\hline $\begin{array}{c}\text { Body temperature } \\
{\left[{ }^{\circ} \mathrm{C}\right]}\end{array}$ & $35.66 \pm 1.52$ & $22.82 \pm 1.56^{*}$ & $23.75 \pm 0.8^{\star}$ \\
\hline $\begin{array}{l}\text { Post-exercise temperature } \\
\text { of blood flowing from the } \\
\text { femoral vein and artery } \\
\qquad\left[{ }^{\circ} \mathrm{C}\right]\end{array}$ & $32.66 \pm 1.52$ & $22.25 \pm 1.58^{\star}$ & $23.22 \pm 0.58^{\star}$ \\
\hline
\end{tabular}

${ }^{*}$ significantly different compared to controls $(P<0.05)$

rats swimming in water at $25^{\circ} \mathrm{C}$ ) compared to control group IV, by $11.91^{\circ} \mathrm{C}$ (Table 3 ).

The values of post-exercise temperature of blood flowing from the femoral vein and artery decreased in group $\mathrm{V}$ (in 36-week old rats swimming in water at $4^{\circ} \mathrm{C}$ ) compared with the control group IV, by $10.41^{\circ} \mathrm{C}$, and in group VI (in 36-week old rats swimming in water at $25^{\circ} \mathrm{C}$ ) compared with control group IV, by $9.44^{\circ} \mathrm{C}$ (Table 3).

\section{Morphological parameters}

In post-hoc tests it was found that the mean number of erythrocytes was significantly higher in group II (8-week old rats swimming in water at $\left.4^{\circ} \mathrm{C}\right)$ in comparison with the control group I (by 15.6\%) and in comparison with group III (8-week old rats swimming in water at $25^{\circ} \mathrm{C}$ ) (Table 4$)$.

In post-hoc tests, the mean values for hemoglobin were significantly higher in group II (8-week old rats swimming in water at $4^{\circ} \mathrm{C}$ ) in comparison with the control group I (by $36.7 \%$ ), in comparison with group III (8-week old rats swimming in water at $25^{\circ} \mathrm{C}$ ), and the latter in comparison with control group I (by 27.4\%) (Table 4).
In post-hoc tests, the mean hematocrit value was significantly higher in group II (8-week old rats swimming in water at $4^{\circ} \mathrm{C}$ ) in comparison with the control group I (by 20.7\%), and in the comparison with group III (8-week old rats swimming in water at $25^{\circ} \mathrm{C}$ ), and the latter in comparison of with the control group I (by $10.9 \%$ ) (Table 4 ).

In post-hoc tests, the mean $\mathrm{MCH}$ value was significantly higher in group II (8-week old rats swimming in water at $4^{\circ} \mathrm{C}$ ) when compared to the control group I (by $12.6 \%$ ) and in the comparison between group III (8-week old rats swimming in water at $25^{\circ} \mathrm{C}$ ) and the control group I (by 12,1\%) (Table 4). After an additional analysis of bilateral comparisons for MCHC, it turned out that the value of the median was significantly higher in group II (8-week old rats swimming in water at $4^{\circ} \mathrm{C}$ ) compared with the control group I (by $12.8 \%$ ) and in the comparison between group III (8-week old rats swimming in water at $25^{\circ} \mathrm{C}$ ) and the control group I (by 14.6\%).

In post-hoc tests, the mean leucocyte count was significantly higher in group II (8-week old rats swimming in water at $4^{\circ} \mathrm{C}$ ) compared with the control group I (by $41.8 \%$ ) and with group III (8-week old rats swimming in water at $25^{\circ} \mathrm{C}$ ) (Table 4 ).

Table 4. Mean values $( \pm S D)$ for $R B C, W B C, H G B, H t, P L T, M C H, M C V$, retikulocytes, poikilocytes in 8-week old rats, swimming in water at $4^{\circ} \mathrm{C}, 25^{\circ} \mathrm{C}$, and in the control group

\begin{tabular}{|c|c|c|c|}
\hline \multirow[b]{2}{*}{ Morphological parameters } & \multicolumn{3}{|c|}{ Groups of 8-week old rats } \\
\hline & $\begin{array}{l}\text { group I } \\
\text { control }\end{array}$ & $\begin{array}{c}\text { group II } \\
\text { swimming at } 4^{\circ} \mathrm{C}\end{array}$ & $\begin{array}{c}\text { group III } \\
\text { swimming at } 25^{\circ} \mathrm{C}\end{array}$ \\
\hline $\mathrm{RBC}\left[106 / \mathrm{mm}^{3}\right]$ & $7.06 \pm 0.2$ & $8.16 \pm 0.32^{\star}, * *$ & $7.65 \pm 0.39$ \\
\hline $\mathrm{WBC}\left[10^{3} / \mathrm{mm}^{3}\right]$ & $9.60 \pm 1.086$ & $5.59 \pm 1.17^{\star}, * *$ & $9.82 \pm 1.33$ \\
\hline $\mathrm{HGB}[\mathrm{g} / \mathrm{dl}]$ & $12.8 \pm 0.99$ & $17.5 \pm 0.9^{*}, \star *$ & $16.3 \pm 0.83^{*}$ \\
\hline Ht [\%] & $37.6 \pm 2.09$ & $45.4 \pm 2.28^{\star}, * *$ & $41.7 \pm 2.72^{\star}$ \\
\hline $\operatorname{PLT}\left[10^{3} / \mathrm{mm}^{3}\right]$ & $272.4 \pm 95.6$ & $365 \pm 119.7$ & $412 \pm 125.8$ \\
\hline $\mathrm{MCH}[\mathrm{pg}]$ & $19.0 \pm 0.86$ & $21.4 \pm 0.74^{\star}$ & $21.3 \pm 0.64^{*}$ \\
\hline $\operatorname{MCV}\left[\mu \mathrm{m}^{3}\right]$ & $56.4 \pm 3.78$ & $55.5 \pm 1.58$ & $54.66 \pm 2.12$ \\
\hline reticulocytes [\%o] & $4.00 \pm 1.871$ & $5.13 \pm 1.960$ & $3.90 \pm 1.853$ \\
\hline poikilocytes [\%] & $1.33 \pm 0.816$ & $1.33 \pm 1.506$ & $2.67 \pm 1.366$ \\
\hline
\end{tabular}

${ }^{*}$ significantly different compared to controls $(P<0.05)$

${ }^{*}$ significantly different between groups II and III $(P<0.05)$ 
Table 5. Mean values $( \pm S D)$ for RBC, WBC, HGB, Ht, PLT, MCH, MCHC, MCV, retikulocytes, poikilocytes in 36-week old rats, swimming in water at $4^{\circ} \mathrm{C}, 25^{\circ} \mathrm{C}$, and in the control group

\begin{tabular}{cccc}
\hline Morphological parameters & group IVcontrol & $\begin{array}{c}\text { Groups of 36-week old rats } \\
\text { group Vat } 4{ }^{\circ} \mathrm{C}\end{array}$ & group VIat $25^{\circ} \mathrm{C}$ \\
\hline $\mathrm{RBC}\left[106 / \mathrm{mm}^{3}\right]$ & $8.0 \pm 0.38$ & $8.28 \pm 0.14$ & $8.06 \pm 0.44$ \\
$\mathrm{WBC}\left[10^{3} / \mathrm{mm}^{3}\right]$ & $6.6 \pm 0.26$ & $9.45 \pm 3.92$ & $11.87 \pm 5.6$ \\
$\mathrm{HGB}[\mathrm{g} / \mathrm{dl}]$ & $13.3 \pm 0.96$ & $15.38 \pm 0.54$ & $14.81 \pm 1.15$ \\
$\mathrm{Ht}[\%]$ & $41.26 \pm 2.56$ & $43.87 \pm 1.29$ & $42.26 \pm 3.04$ \\
$\mathrm{PLT}\left[10^{3} / \mathrm{mm}^{3}\right]$ & $189.33 \pm 81.15$ & $545.5 \pm 100.88^{*}$ & $456.0 \pm 171.98$ \\
$\mathrm{MCH}[\mathrm{pg}]$ & $16.66 \pm 0.65$ & $18.57 \pm 0.65^{*}$ & $18.33 \pm 0.96$ \\
$\mathrm{MCHC}[\mathrm{g} / \mathrm{dl}]$ & $32.3 \pm 0.5$ & $35.1 \pm 0.82^{*}$ & $34.97 \pm 0.62^{*}$ \\
$\mathrm{MCV}\left[\mu \mathrm{m}^{3}\right]$ & $51.66 \pm 1.52$ & $53.0 \pm 1.6$ & $52.37 \pm 2.56$ \\
reticulocytes $[\%]$ & $2.75 \pm 0.85$ & $5.0 \pm 2.24$ & $3.89 \pm 2.76$ \\
poikilocytes[\%] & $1.44 \pm 0.89$ & $1.83 \pm 0.98$ & $1.5 \pm 1.52$ \\
\hline
\end{tabular}

${ }^{*}$ significantly different compared to controls $(P<0.05)$

${ }^{* *}$ significantly different between groups $\mathrm{V}$ and VI $(P<0.05)$

Table 6. Post-hoc comparisons (P values) of body temperature and post exercise temperature of blood in 8-and 36-week-old rats

\begin{tabular}{|c|c|c|c|c|c|c|c|}
\hline & & \multicolumn{3}{|c|}{ Body temperature $\left[{ }^{\circ} \mathrm{C}\right]$} & \multicolumn{3}{|c|}{$\begin{array}{l}\text { Post-exercise temperature of blood flowing } \\
\text { from the femoral vein and artery }\left[{ }^{\circ} \mathrm{C}\right]\end{array}$} \\
\hline & & \multicolumn{6}{|c|}{ Groups of 36-week-old rats } \\
\hline & & IV & $\mathrm{V}$ & VI & IV & V & $\mathrm{V}$ \\
\hline \multirow{3}{*}{$\begin{array}{l}\text { Groups of } \\
\text { 8-week-old } \\
\text { rats }\end{array}$} & I & - & 0.00013 & 0.00013 & - & 0.00013 & 0.00013 \\
\hline & II & 0.00013 & 0.0022 & 0.000152 & 0.00013 & - & - \\
\hline & III & 0.00013 & 0.0059 & - & 0.00013 & 0.000524 & 0.048 \\
\hline
\end{tabular}

Table 7. Post-hoc comparisons (P values) of RBC counts and HGB and Ht concentrations in 8- and 36-week-old rats

\begin{tabular}{ccccccccccc}
\hline & \multicolumn{4}{c}{ RBC $\left[106 / \mathrm{mm}^{3}\right]$} & \multicolumn{4}{c}{ HGB [g/dl] } & \multicolumn{3}{c}{ Ht [\%] } \\
& & \multicolumn{4}{c}{} & \multicolumn{4}{c}{ Groups of 36-week-old rats } \\
& & IV & V & VI & IV & V & VI & IV & V & VI \\
\hline Groups of & I & 0.007213 & 0.000137 & 0.000249 & - & 0.000773 & 0.011819 & - & 0.002623 & 0.042743 \\
8-week-old & II & - & - & 0.037789 & 0.000147 & 0.000654 & 0.000137 & - & - & - \\
rats & III & - & - & - & 0.002927 & - & 0.023482 & - & - & - \\
\hline
\end{tabular}

In post-hoc tests, the mean $\mathrm{MCH}$ value was significantly higher in group V (36-week old rats swimming in water at $4^{\circ} \mathrm{C}$ ) compared with control group IV (by 11.46\%) (Table 5).

In post-hoc tests, the mean $\mathrm{MCHC}$ value was significantly higher in group V (36-week old rats swimming in water at $4^{\circ} \mathrm{C}$ ) compared with the control group IV (by 7.98\%) and in the comparison of group VI (36-week old rats swimming in water at $25^{\circ} \mathrm{C}$ ) with control group IV (by 8.24\%) (Table 5).

The mean PLT count in post-hoc tests was significantly higher in group V (36-week old rats swimming in water at $4^{\circ} \mathrm{C}$ ) compared with control group IV (by $188,12 \%$ ) (Table 5).

\section{Comparison of parameters analyzed in 8-and 36-we-} ek-old rats

On post-hoc tests, mean body temperatures in animals of groups V and VI were significantly lower compared to group I. Mean body temperature in group II was significantly lower than in groups IV, V and VI, and mean temperature in group III was significantly lower compared to groups IV and V.

Additionally, post-hoc tests revealed that an average post exercise temperatures of blood in groups $\mathrm{V}$ and VI were significantly lower than in group I. The average post exercise temperatures in groups II and III were significantly lower compared to group IV, and groups IV, V and VI, respectively. 
Table 8. Post-hoc comparisons (P values) of $M C H C, M C H$ and $M C V$ levels in 8- and 36-week-old rats

\begin{tabular}{|c|c|c|c|c|c|c|c|c|c|c|}
\hline & & \multirow{2}{*}{\multicolumn{3}{|c|}{$\mathrm{MCHC}[\mathrm{g} / \mathrm{dl}]$}} & \multicolumn{3}{|c|}{$\mathrm{MCH}[\mathrm{pg}]$} & \multicolumn{3}{|c|}{$\mathrm{MCV}\left[\mu \mathrm{m}^{3}\right]$} \\
\hline & & & & & \multicolumn{3}{|c|}{ Groups of 36-week-old rats } & \multirow[b]{2}{*}{ IV } & \multirow[b]{2}{*}{$\mathrm{V}$} & \multirow[b]{2}{*}{ VI } \\
\hline & & IV & V & VI & IV & V & VI & & & \\
\hline \multirow{3}{*}{$\begin{array}{l}\text { Groups of } \\
\text { 8-week-old } \\
\text { rats }\end{array}$} & $\mathrm{I}$ & - & 0.00013 & 0.00013 & - & - & - & - & - & - \\
\hline & II & 0.00013 & 0.00013 & 0.00013 & 0.00013 & 0.00013 & 0.00013 & - & - & - \\
\hline & III & 0.00013 & 0.00013 & 0.00013 & 0.00013 & 0.00013 & 0.00013 & - & - & - \\
\hline
\end{tabular}

Table 9. Post-hoc comparisons (P values) of WBC and PLT counts in 8- and 36-week-old rats

\begin{tabular}{cccccccc}
\hline & & \multicolumn{3}{c}{$\mathrm{WBC}\left[10^{3} / \mathrm{mm}^{3}\right]$} & \multicolumn{4}{c}{ PLT $\left[10^{3} / \mathrm{mm}^{3}\right]$} \\
& & & \multicolumn{4}{c}{ Groups of 36-week-old rats } \\
& & IV & V & VI & IV & V & VI \\
\hline \multirow{2}{*}{$\begin{array}{c}\text { Groups of 8-week- } \\
\text {-old rats }\end{array}$} & I & - & - & - & - & 0.017078 & - \\
& II & - & - & 0.012051 & - & - & - \\
\hline
\end{tabular}

The results of post-hoc tests revealed that mean RBC count in animals of group IV was significantly higher than in group I. In group V, mean RBC count was significantly higher than in group I, while in groups VI and II - significantly higher compared to group I and VI, respectively.

Mean HGB level was significantly higher in group V when compared to group I, in group VI compared to group I, group II compared to groups IV, V and VI, and group III compared to groups IV and VI.

Both in groups V and VI, mean concentrations of Ht were significantly higher than in group w I.

On post-hoc tests, mean values of $\mathrm{MCHC}$ in groups $\mathrm{V}$ and VI were significantly higher compared to group I. Both in groups II and III, MCHC levels were significantly higher compared to groups IV, V and VI.

Both in group II and III, mean values of $\mathrm{MCH}$ bwere significantly higher than in groups IV, V and VI.

Post-hoc tests revealed that mean WBC count in group VI was significantly higher than $\mathrm{n}$ group II.

Mean PLT count, in turn, was significantly higher in group V compared to group I.

\section{Discussion}

The results obtained in this study, indicating fluctuations in the morphological parameters in blood of rats swimming at $4^{\circ} \mathrm{C}$ and $25^{\circ} \mathrm{C}$, are affected by a number of factors; namely: physical exercise (causing a decrease in volume of plasma which hampers inflow of blood and the heat transfer to the skin), stress associated with low temperature, and marked stenosis of peripheral blood vessels (entailing excessive strain on more centrally situated vessels). Not all these causes of the above phenomena have been thoroughly studied yet. In our research, in the group of 8-week old rats (in group II or III) increases were noted in the erythrocyte count, hemoglobin, and hematocrit. In the animals comprising group II (swimming in water at $4{ }^{\circ} \mathrm{C}$ ) compared with control group I, increases were noted in the levels of erythrocyte count, hemoglobin, and hematocrit, whereas in group III (swimming in water at $25^{\circ} \mathrm{C}$ ) when compared with control group I, increases were found in the values for $\mathrm{Hb}$ and $\mathrm{Ht}$. These results support the thesis that physical exercise in 8-week old rats affects hemoconcentration and increases the values of blood parameters to a much greater extent than in the group of 36-week old rats (groups V, VI). In group $\mathrm{V}$, however (rats swimming in water at $4^{\circ} \mathrm{C}$ ) compared to control group IV, statistically significant increases were noted in $\mathrm{MCHC}$ and $\mathrm{MCH}$, and in group VI, when compared to the control group IV, an increase was found only in the MCHC index.

These changes may not necessarily be caused by exercise, but by the greater impact of cold water, stress or more frequent urination. The changes in hemoglobin content affect certain parameters of blood cells as: mean corpuscular volume (MCV), mean corpuscular hemoglobin $(\mathrm{MCH})$, and mean cell hemoglobin concentration (MCHC). In studies carried out in humans, significant increases in $\mathrm{MCV}, \mathrm{MCH}, \mathrm{MCHC}$, and hemoglobin during a 12-week swimming training period was observed by Mujika et al. [14]. Cordova et al. [15] did not find changes in $\mathrm{MCV}, \mathrm{MCH}$, and $\mathrm{MCHC}$ despite the increased levels of red blood cell count, hematocrit and hemoglobin during a single swimming exercise. In our study, marked increases in $\mathrm{MCHC}$ and $\mathrm{MCH}$ were found both in group I (8week old rats swimming in water at $4^{\circ} \mathrm{C}$ ), and group III (animals swimming in water at $25^{\circ} \mathrm{C}$ ) when compared with control group I. These changes correlate with the 
increases in $\mathrm{RBC}, \mathrm{Hb}$, and $\mathrm{Ht}$ found in group II (animals swimming in water at $4^{\circ} \mathrm{C}$ ) compared with the control group I. In 8-week old rats swimming in water at $25^{\circ} \mathrm{C}$ (group III) compared with the control group I, however, these changes correlate with increases in $\mathrm{Hb}$ and $\mathrm{Ht}$. In both 8-week old and 36-week old rats there were no significant differences in MCV.

In long-distance swimmers (5200 $\pm 618 \mathrm{~m}$ ) over 90 minutes, leucocytosis was noted without any changes in erythrocytes, hemoglobin, and hematocrit [17]. In our study, the decrease in the leucocyte counts were observed in 8-week old rats swimming in water at $4^{\circ} \mathrm{C}$, compared with the control group. And besides this, when comparing 8-week old animals in group II (swimming in water at $4^{\circ} \mathrm{C}$ ) with the rats in group III (swimming at $25^{\circ} \mathrm{C}$ ), a lower mean value of WBC occurred in the former group. Perhaps, the reduced body temperature slowed blood circulation and resulted in a lower release of leucocytes from the bone marrow into the blood circulation system. Deveci et al. [18] suggested that marked leucopenia in rats acclimated from a temperature of $20^{\circ} \mathrm{C}$ to a temperature of $4^{\circ} \mathrm{C}$, should reduce the degree of microvascular blockade, which might help maintain the perfusion of the microcirculation. The post-exercise decrease in eosinophilia during swimming at $0^{\circ} \mathrm{C}$ was also observed by Miettinen [18], who attributed it to the increases cortical-adrenal activity.

A slight increase in the platelet (PLT) count may be related to the effect of a lower temperature on hemoconcentration [20]. In our study, on 36-week old rats, the increase in the number of blood platelets was noted when a comparison was made between group $\mathrm{V}$ (swimming in water at $4{ }^{\circ} \mathrm{C}$ ) and the control group IV.

Despite the changes in the number of the morphotic elements of blood occurring during physical exercise in water at $4^{\circ} \mathrm{C}$ and $25^{\circ} \mathrm{C}$, no increases or decreases were observed in the reticulocyte counts, or in the number RBC with changed shapes (poikilocytosis). Perhaps, the duration of exercise was too short to cause any significant changes in reticulocyte and poikilocyte counts. In the examinations of abnormal shapes of erythrocytes, only microcytes, macrocytes, echinocytes and drepanocytes were discerned sporadically, once in several microscopic fields. In our study, the most commonly sighted reticulocytes were those from group I and II in the divisions introduced by Heilmeyer and Trachtenberg [11] i.e. close to the appearance of acidophilous erythroblasts, which is indicative of a normal function of the bone marrow. There are also other publications where no changes were noted in the number of reticulocytes after exercise or training $[21,22]$, but the authors of these studies conclude that the amount of exercise applied by them in the experiments was too low to provoke changes in the number of reticulocytes in humans who undergone training.
Additionally, in our research on 8-week and 36week old rats, the decreases were noted - as expected - in both body temperature and blood temperature after swimming, which is an obvious phenomenon, particularly at $4^{\circ} \mathrm{C}$. The body temperature measured in the rectum in 8-week old rats swimming in water at $4^{\circ} \mathrm{C}\left(4.42\right.$ minutes) decreased by $17.2^{\circ} \mathrm{C}$, whereas in water at $25^{\circ} \mathrm{C}\left(60\right.$ minutes) - by $5.8^{\circ} \mathrm{C}$ (Table 2$)$. In 36 -week old animals swimming in water at $4^{\circ} \mathrm{C}(4.92$ minutes) the body temperature dropped by $12, .84^{\circ} \mathrm{C}$, whereas in water at $25^{\circ} \mathrm{C}$ (60 minutes) - by $11.91^{\circ} \mathrm{C}$ (Table 2). These fluctuations are essentially affected by the age of rats, water temperature, and duration of swimming. The most recent research published by Knechtle et al. [23] indicate that 20-minute swimming in water at $4^{\circ} \mathrm{C}$ by a human resulted in a decrease in body temperature to $32^{\circ} \mathrm{C} 20$ minutes after coming out of the water.

The post-exercise values of temperature of blood flowing from the femoral vein and artery in 8-week old rats, swimming in water at $4^{\circ} \mathrm{C}$ decreased by $10.5^{\circ} \mathrm{C}$, and compared with the group of rats swimming in water at $25^{\circ} \mathrm{C}-$ by $11.91^{\circ} \mathrm{C}$. However, in 36 -week old rats swimming in water at $4^{\circ} \mathrm{C}$ it decreased by $10.41^{\circ} \mathrm{C}$ compared with control group, and in 36-week old rats swimming in water at $25^{\circ} \mathrm{C}$ by $9.44^{\circ} \mathrm{C}$ (Table 3 ). Despite the differences in age and water temperature, the measurements of post-exercise temperature made in blood flowing from the femoral vein and artery are similar.

\section{Comparison of parameters analyzed in young and old rats}

This study revealed age-related differences in blood morphology. Decreased temperature of body and blood along with increased levels of RBC, HGB, $\mathrm{Ht}, \mathrm{MCHC}$, and $\mathrm{MCH}$ induced hemoconcentration, both in 8-and 36-week-old rats. The plasma volume changes could be imputed to the shift of plasma water from the intra - to the extravascular compartments, due to the sympathetic system activation and the consequent reactive vasoconstriction [24]. The cold induced PLT count increase, along with the cold - induced leukocytosis that is a well - known risk factor for ischemic vascular disease morbidity and mortality [25]. The increased number of the WBC set seems to be due to a direct induction of the hematopoiesis at the bone marrow level under the pull of the sympathetic activity through the activation of a series of hormonal mediators, regulating the energy metabolism and the cold adaptation and among them leptin [25].

\section{Conclusions}

The increase in most parameters of blood morphology testifies to the dehydration of organism during exercise which affects microcirculatory function. The 
unchanged reticulocyte count in peripheral blood may prove that there is no effect exerted by low temperatures on the function of the bone marrow.

\section{Declaration of interest}

The authors report no conflicts of interest.

\section{References}

1. Vogelaere P, Savourey G, Deklunder G, et al. Reversal of cold induced haemoconcentration. Eur J Appl Physiol 1992; 64(3): 244-9.

2. Deveci D, Stone PCW, Egginton S. Differential effect of cold acclimation on blood composition in rats and hamsters. J Comp Physiol B 2001; 171: 135-43.

3. Ruckman KS, Sherman AR. Effects of exercise on iron and copper metabolism in rats. J Nutr 1981; 111: 1593-601.

4. Devi SA, Subramanyam MVV, Vani R. Adaptation of the antioxidant system in erythrocytes of trained adults rats: Impact of intermittent hypobaric-hypoxia at two altitudes. Comp Biochem Physiol C 2005; 140(1): 59-67.

5. Holmer I. Physiology of swimming man. Acta Physiol Scand 1997; 407(Suppl): 142-9.

6. Selby GB, Eichner ER. Endurance swimming, intravascular hemolysis, anemia and iron depletion. New perspective on athlete's anemia. Am J Med 1986; 81(5): 791-4.

7. Brylińska J, Kwiatkowska J. Zwierzęta laboratoryjne. Metody hodowli i doświadczeń. Kraków: Towarzystwo Autorów i Wydawców Prac Naukowych UNIVERSITAS, 1996.

8. Zeman V, Holeček V, Novák J. Funkce ledvin pŕi plaváni v ledovè a teplè vodè $\mathrm{u}$ osob adaptovaných $\mathrm{k}$ chladu. Čas Lék Čes 1983; 122: 143-6.

9. Pińkowski R. 18-parametrowe analizatory hematologiczne. Warszawa: ABX Diagnostics Polska, 2001.

10. Heath C, Daland G. Staining of reticulocytes with Brilliant Cresyl Blue. Arch Int Med 1931; 48: 133-45.

11. Heilmeyer L. Blutfarbstoffwechselstudien I. Dtsch Arch Klin Med 1931; 171: 123-53.

12. Chirico M, Manzotti M. Review of the concept of poikilocytosis, resistance to deformation in normal subject. Haematologica 1952; 36(9): 971-81.

13. Holowinska C. Poikilocytosis. Can J Med Technol 1957; 19(4):137-41.

14. Mujika I, Padilla S, Geyssant A, et al. Hematological responses to training and taper in competitive swimmers: relationship with performance. Archiv Physiol Biochem 1998; 105(4): 379-85.

15. Cordova A, Navas FJ, Escanero JF. The effect of exercise and zinc supplement on the hematological parameters in rats. Biol Trace Elem Res 1993; 39(1): 13-20.

16. Wood JG, Johnson JS, Mattioli LF, et al. Systemic hypoxia increases leukocyte emigration and vascular permeability in conscious rats. J Appl Physiol 2000; 89(4): 1561-8.
17. Haralambie G, Senser L. Metabolic changes in man during long-distance swimming. Eur J Appl Physiol 1980; 43(2): 115-25.

18. Deveci D, Stone PCW, Egginton S. Differential effect of cold acclimation on blood composition in rats and hamsters. $J$ Comp Physiol B 2001; 171: 135-43.

19. Miettinen M. Effect of swimming in ice-cold water on the blood picture. Ann Med Intern Fenn 1954; 43(4): 298-304.

20. Vogelaere P, Brasseur M, Quirion A, et al. Hematological variations at rest and during maximal and submaximal exercise in cold $\left(0^{\circ} \mathrm{C}\right)$ environment. Inter J Biometeorol 1990; 34(1): 1-14.

21. Banfi G, Mauri C, Morelli B, et al. Reticulocyte count, mean reticulocyte volume, immature reticulocyte fraction and mean sphered cell volume in elite athletes; reference values and comparison with the general population. Clin Chem Lab Med 2006; 44(5): 616-22.

22. Londeree BR, Allaire T. Reticulocyte counts before and after exercise: trained vs. sedentary. Eur J Appl Physiol 1969; 27: 226-9.

23. Knechtle B, Christinger N, Kohler G, et al. Swimming in ice cold water. Ir J Med Sci 2009; 178(4): 507-11.

24. Pendergast DR, Lundgren CEG. The underwater environment: cardiopulmonary, thermal, and energetic demands. $J$ Appl Physiol 2009; 106: 276-83

25. Coller BS. Leucocytosis and ischemic vascular disease morbidity and mortality: is it time to intervene? Arterioscler. Thromb Vasc Biol 2005; 25: 658-70

Received: March 18, 2011

Accepted: November 15, 2011

Published: November 23, 2011

Address for correspondence:

Aneta Teległów PhD,

Department of Clinical Rehabilitation

University School of Physical Education

Al. Jana Pawła 78,

31-571 Cracow, Poland

Tel.: +48 126831083

Fax: +48 126831300

E-mail: aneta.teleglow@awf.krakow.pl

Aneta Teległów: aneta.teleglow@awf.krakow.pl

Jan Bilski: mpbilski@cyf-kr.edu.pl

Zbigniew Dąbrowski: kasprowicza19@poczta.fm

Anna Marchewka: anna.marchewka@awf.krakow.pl

Jerzy Jaśkiewicz: jjaskiewicz@afm.edu.pl

Jacek Głodzik: jacek.glodzik@awf.krakow.pl

Magdalena Kępińska: m.kepinska@tlen.pl

Dorota Lizak: doroli3@interia.pl

\begin{tabular}{llll}
\hline Authors' contribution & B - Data Collection & D - Data Interpretation & F - Literature Search \\
A - Study Design & C - Statistical Analysis & E - Manuscript Preparation & G - Funds Collection
\end{tabular}

